\title{
Eamon MAHER, Eugene O'BRIEN, Tracing the Legacy of Irish Catholicism. From Galway to Cloyne and Beyond, Manchester, Manchester University Press, 2017
}

\section{Alexandra Slaby}

\section{(2) OpenEdition}

1 Journals

\section{Electronic version}

URL: http://journals.openedition.org/etudesirlandaises/5410

DOI: 10.4000/etudesirlandaises.5410

ISSN: 2259-8863

\section{Publisher}

Presses universitaires de Caen

\section{Printed version}

Date of publication: 29 November 2017

Number of pages: 166-167

ISBN: 978-2-7535-7388-8

ISSN: 0183-973X

\section{Electronic reference}

Alexandra Slaby, «Eamon Maher, Eugene O'Brien, Tracing the Legacy of Irish Catholicism. From Galway to Cloyne and Beyond, Manchester, Manchester University Press, 2017 "Études irlandaises [Online], 42-2 | 2017, Online since 29 November 2017, connection on 24 September 2020. URL : http:// journals.openedition.org/etudesirlandaises/5410; DOI : https://doi.org/10.4000/etudesirlandaises. 5410

\section{cc) (†) (2)}

Études irlandaises est mise à disposition selon les termes de la Licence Creative Commons Attribution - Pas d'Utilisation Commerciale - Partage dans les Mêmes Conditions 4.0 International. 
Eamon Maher, Eugene O'Brien, Tracing the Legacy of Irish Catholicism. From Galway to Cloyne and Beyond, Manchester, Manchester University Press, 2017, 248 p., ISBN 978-1-5261-0106-8, £85.00.

This volume is the latest study of the challenges and prospects of contemporary Irish Catholicism. The word "legacy" suggests that the contributors write on the assumption that Irish Catholicism is dead. What is Irish Catholicism, and what about it is dead? To answer these questions, the editors look at Irish Catholicism with cultural lenses, bringing together academic contributors across the spectrum of the humanities as well as voices from the Church and the media.

What happened between Galway and Cloyne? The first section contextualizes the changing relationship between the Catholic Church and the population. The second draws attention to critical voices, and the third presents the challenges that lie on the horizon as Irish Catholicism may face death by "Eucharistic famine" and as Ireland watches its "Catholic twilight".

In the legacy, one finds the Entweltlichung of the Irish Church, its association with state - and identity-building resulting in "the sacred being corrupted by the political", the Catholic label being loosely and meaninglessly attached to institutions. It may come as a surprise to find among the proponents of disentanglement a cleric, Fr Vincent Twomey, seen as a spokesperson of conservative Catholicism because he was a doctoral student of Cardinal Ratzinger. Maher points out very rightly that Fr Twomey's views are in fact radical.

Parting with those inherited circumstances would enable the Catholic Church in Ireland to be more faithful to the "life-giving word of God", to become a Church characterized by a service-oriented pastoral approach. A Church that would re-engage the religious imagination through art and poetry, and that would recover its theological and spiritual heritage and transmit it from the pulpit during substantial Sunday homilies.

Eamon Maher and Catherine Maignant introduce to us "prophetic" or dissident voices from the Irish and French clergy whose bold utterances or warnings compel the reader to reflect upon what is to be held as an eternal truth and what is a matter of circumstance that can be reformed. One such prophetic voice is that of Fr Twomey whose ideas to foster the dawn of a reflective Catholicism in Ireland involve Catholic academies on the German and Austrian model. The clergy also needs to be better trained in theological basics and not only in managerial skills. What is at stake? As Eugene O'Brien shows in a thought-provoking transposition of Terry Pratchett's Omnia to an Irish Church, a Church that is too big and too heavy risks becoming an empty shell that will have allowed God to wither away. But the decline of organized religion does not "inevitably or directly lead to positive gains for rational or humanist thinking"; it can also lead to superstition, to a 
diffuse and syncretic spirituality or to the replacement of one transcendence by another, the market of neoliberal materialism.

Among its many qualities (expertise and diversity of the contributors, construction of the sequence of chapters), this volume distinguishes itself by its dispassionate tone. It succeeds in avoiding the pro- or anti-Catholic stance. Joe Cleary invites the Irish Catholic world to move from "dead certainties" to "intelligent questions." This book will definitely contribute enormously to accomplishing that transition.

Alexandra SLABY

Raphaël Ingelbien, Irish Cultures of Travel: Writing on the Continent, 1829-1914, London, Palgrave Macmillan, 2016, Ix + 252 p., ISBN 978-1-137-56784-0 (ebook) \$69.99, ISBN 978-1-137-56783-3 (hardcover) \$95.00.

The publication of Raphäl Ingelbien's Irish Cultures of Travel is symptomatic of a growing scholarship on the history of Irish travel abroad and Irish travel writing. Indeed, the book breaks new ground in that it represents the first attempt to chart Irish travel out of Ireland in the long nineteenth century. To date, most of the research in the field has been devoted to travel and tourism in Ireland. In a century marked by massive emigration out of Ireland, it is also understandable that Irish tourism abroad in the period has been overshadowed. The book's timeline, set between Catholic Emancipation in 1829 and the breakout of World War I, allows the author to investigate the travelling cultures of the Victorian and Edwardian Irish middle classes, including a growing Catholic middle class, in a more systematic way than has ever been done before. The term "cultures of travel" is very apt inasmuch as the Irish travelled abroad for a variety of reasons and with diverse experiences and backgrounds.

The book quotes from a wide range of sources, including many anonymous articles in the contemporary press. It also includes the writings of, for example, Mathew O'Conor, Thomas Davis and Selina Martin. Except for an excursion into James Joyce's 'The Dead', the book shifts attention away from canonical literature, turning the spotlight on texts that provide "evidence of remarkable cultural trends" (p. 12). The "reader-oriented approach" claimed in the book is not, however, a reader-response approach as such; rather, the focus is on public discourse. Public discourse on Irish travel shows that national, political and religious identities were often at stake. Such discourse would convey, for example, utilitarian agendas, anti-modern ideas and/or cultural nationalist programmes. Among 